

Cuadernos de $\mathrm{H}$ ideas

ISSN: 2313-9048

cuadernosdehideas@perio.unlp.edu.ar

Universidad Nacional de La Plata

Argentina

\title{
Literatura infantil, escuela y construcción de subjetividad. Conversaciones con Laura Devetach
}

\author{
Figueroa, Mario \\ Literatura infantil, escuela y construcción de subjetividad. Conversaciones con Laura Devetach \\ Cuadernos de $\mathrm{H}$ ideas, vol. 13, núm. 13, e022, 2019 \\ Universidad Nacional de La Plata, Argentina \\ DOI: https://doi.org/10.24215/23139048e022
}

Esta obra está bajo una Licencia Creative Commons Atribución-NoComercial-Compartirlgual 4.0 Internacional. 
Entrevista

\title{
Literatura infantil, escuela y construcción de subjetividad. Conversaciones con Laura Devetach
}

\author{
Mario Figueroa mariohfigueroa2005@yahoo.com.ar \\ Universidad Nacional del Comahue, Argentina
}

Recibido: 10/05/19

Aceptado: 29/05/19

Publicado: 18/09/19

DOI: https://doi.org/10.24215/23139048e022

\section{Entrevista a: Laura Devetach}

Escritora. Doctora Honoris Causa de la Universidad Nacional de Córdoba. Licenciada en Letras Modernas. Publicó numerosos títulos para niños y adultos en los géneros poesía, narrativa, teatro y reflexiones teóricas. Parte de esta obra fue publicada en otros países. Creó y dirigió colecciones de libros para niños y coordinó durante más de diez años un taller laboratorio sobre procesos creativos en relación a la lectura y a la escritura. Ejerció el periodismo y colabora en publicaciones especializadas. Trabajó en la docencia terciaria y universitaria. Recibió, entre otros, los premios Casa de las Américas por su libro Monigote en la arena; y del Fondo Nacional de las Artes por La torre de cubos y Para que sepan de mi; el premio Octogonal del Centre International d'Etudes en Litterature de Jeunesse, Francia y el Premio Pregonero a la Trayectoria, otorgado por la Fundación El Libro. En 2004 recibió el Diploma al mérito Konex en Literatura Infantil y en 2010 el Premio S.M.Iberoamericano de Literatura Infantil y Juvenil. Entre sus títulos para adultos figuran: La construcción del camino lector y Oficio de palabrera. De su obra para niños: La Plaza del Piolin, Picaflores de cola roja, El enigma del barquero, Canción y pico, Noche de luna llena, La hormiga que canta, Cositos, Avión que va, avión que llega, Periquito.

La experiencia como una de las escritoras reconocidas en el ámbito de la literatura infantil, la convierte en una voz a la que le sobra autoridad para pensar acerca de los sentidos que usualmente le damos a la lectura para chicos.

Los orígenes de Laura Devetach como maestra reflejan una impronta que atraviesa toda su vida: la de caminar sobre los bordes, la de desafiar lo instituido, la de desbordar la teoría.

\footnotetext{
"Aquellos (primeros) años fueron acciones directas con la Literatura. Sobre todo en el secundario y en los profesorados contrabandeé toda la Literatura que pude, introduje libros, traté de enseñar a elegir, a gustar. Algo se logró y aún hoy lo recordamos con algunos ex alumnos, actuales colegas. Llevé a Cortázar, a Juan Rulfo, a Arreola, a
} 
Lorca, Guillén Machado, a los profesorados. Porque si habia que formar lectores, habia que leer. No veo otra forma de hacerlo. Leer teorias en los libros sobre cómo se "baja" a los niños la práctica de la lectura, no sirve para nada. Sólo un lector de verdad puede enseñarlo y es, fundamentalmente, con entusiasmo y por contagio."

El universo de la literatura pensado para los chicos suele plantear un laberinto en el que - no pocas veces- uno puede perderse entre prescripciones moralistas y producciones estéticas vacías. Corriendo el velo de esa hojarasca, Laura hace su apuesta e invita a propiciar la lectura de mucha ficción y poesía.

"Con la ficción y la poesía se puede leer al mundo de una manera diferente. Todo se amplia, las palabras dicen más y el que lee va teniendo acceso a su propio espacio poético interno, ese donde viven las cosas que aún no tienen palabras. El diálogo con un texto literario abre esas puertas. Se dialoga también con el autor de una manera privada y autónoma. Ese es uno de los objetivos de acercarse a la Literatura y al arte en general."

Sin embargo la construcción del sentido nunca es un evento solitario, desprovisto de ese otro que es tan importante como el texto mismo. La construcción del camino lector se inicia en y con otros. Siempre es el producto de un acto de compartir, de dejarse descubrir y sorprender, es la riqueza del acto de comunión. En La construcción del camino lector Devetach explica la importancia de unir los textos internos y los textos externos de un cuento o de una poesía.

"Creo que los significados más profundos se codifican con las personas que tenemos al lado. El sentido, se construye en la vida cotidiana. Y transitamos asi hasta el propio secreto, el propio silencio, la privacidad y la autonomía tantas veces temidas, y por las que no peleamos, a veces, lo suficiente.

Para propiciar el encuentro de estos dos mundos, el personal y el colectivo, me parece interesante explorar cómo se van configurando, en cada persona, los trayectos de lectura. Trayectos que finalmente se convierten en caminos, en recorridos siempre renovables que se entraman con lo construido por cada persona apenas abre sus sentidos al mundo."

En sociedad con altos registros de oralidad, no es casual que el ingreso a lo literario esté vinculado con los sentidos que los otros (amigos, padres, maestros) le den a las primeras lecturas. ¿Qué libros se eligen ahí? ¿Cuál es el criterio que prima? ¿Qué otras lecturas se invisibilizan consciente o inconscientemente?

"Siempre los adultos creemos saber cuáles son los gustos y los intereses de los niños respecto a todo. Puede ser, en un sentido superficialy ayudados por los anzuelos que van tirando el mercado, la publicidad y la sociedad de consumo. Pero todas las personas tenemos intereses más profundos que no siempre se manifiestan. Por eso es posible que cada cual haga una lectura distinta de un mismo texto: el mundo interior de cada uno es diferente. Si una obra está bien hecha y no se queda en lo superficial, atrapa. Si está bien hech a pero es ofrecida a lectores poco entrenados, quizás no atrape. Habrá que vencer algunos prejuicios o hacer un camino lector más sólido. No creo que a un chico le interese hoy más una computadora que un gato en un texto literario. Todo depende del sentido profundo que le aporte el texto, su tensión, su trama."

En la historia de Laura Devetach, merece un capítulo aparte los alcances de su libro La torre de cubos, que fuera blanco de la política de censura de la última dictadura (Devetach y Viano, 1976). 
"La torre de cubos fue un lugar de resistencia dentro de la literatura. Muchas maestras y maestros, padres, comunidad educativa, se encargaron de hacerlo circular. A veces en copias mimeográficas. Una vez más, para ellos, mi agradecimiento.

Los motivos de la censura tienen que ver con la ideología del libro que plantea las cosas desde el punto de vista de los chicos y de una concepción del mundo más justa. El edicto de probibición que salió en 1977, entre otras cosa, decía:

Del análisis de La torre de cubos, se desprenden graves falencias tales como simbología confusa, cuestionamientos ideológicos-sociales, objetivos no adecuados al hecho estético, ilimitada fantasía, carencia de estimulos espirituales y trascendente."

De la reflexión, de la práctica, emerge el análisis sobre los límites de una escritura para chicos y una para adultos. Como siempre con Laura Devetach no es posible anclar en la lógica. A pesar de contar con un profundo reconocimiento en la literatura infantil, la escritora reunió en Los desnudos algunos textos que se escapan de la literatura para chicos (Devetach, 1965). ¿Hay un pasaje?¿Un salto?

"En realidad no hay ni salto ni pasaje. Yo simplemente escribia y las oportunidades de publicación fueron marcando el camino. Hay textos que no son ni para chicos ni para grandes. Son oportunidades para el lector. Me pasó más de una vez que, un poema u otro texto escrito "para grandes", se publicó para chicos. Y tuve más oportunidad de trabajar en ese campo."

La vida cotidiana es uno de los elementos centrales de la creación del arte, el mundo conocido, cercano, familiar, que reinventa la propia existencia humana. Para Laura Devetach es ahí donde se inicia todo el camino de la escritura.

En ese devenir la pregunta que se impone tiene que ver con los alcances desde donde pensar cómo construir una literatura infantil. ¿Desde dónde pararse para pensar un criterio?

"Desde donde se construye el arte y toda la literatura, desde la elaboración de la subjetividad para que cada autor vaya encontrando su palabra propia, la más auténtica y, esa palabra, depositada en el mundo cultural, busque y encuentre a su lector que, a su vez, busca un cuento, un poema, y entabla el diálogo con el autor. Si todo ese proceso ayuda para otras cosas (y por supuesto que lo hace), es una consecuencia del proceso creativo eficaz. En fin, creo que es una manera de mirar el mundo. Tía Sidonia por ejemplo, que es un personaje de mis cuentos, es una vieja compañera de vida, una especie de amiga invisible que alguna vez lei en un cuento de infancia. Yo la hice libre y llena de desparpajo. Con el correr del tiempo, vi que tenia mucho que ver con una tía mia que se llamaba Julia y hablaba con un sapo que vivia en su cocina. Hasta que un día descubri que también era un poco yo."

\section{Referencias}

Devetach, L. y Viano, V. (1976). La torre de cubos. Buenos Aires: Librería Huemul.

Devetach, L. (1965). Los Desnudos. Buenos Aires: Ediciones La rosa Blindada. 